\title{
Projection of the oblique line in periapical radiographs of mandibular molars
}

\section{Projeção da linha oblíqua na região de molares inferiores em radiografias periapicais}

\begin{abstract}
Purpose: To identify and quantify the frequency of the projection of the oblique line over the alveolar crests of the mandibular molars in periapical radiographs.

Methods: Five hundred periapical radiographs of the mandibular molar region were selected and evaluated for the presence or absence of the oblique line. When present, its interference on the image of the alveolar crest of the mandibular molars was analyzed. The data obtained was expressed as a percentage of the overlap of the oblique line to the alveolar crests of the mandibular molars.

Results: The oblique line was observed in 363 out of the 500 periapical radiographs (72.6\%). Out of the 363, $308(84.8 \%)$ showed an overlap of the oblique line over the alveolar crests. However, 55 radiographs (15.1\%) did not show such interference. Of the radiographs showing an overlap (308), the incidence of an overlap was $64.6 \%$ at a single site (199 radiographs), $33.4 \%$ at two sites (103 radiographs), and $1.9 \%$ (6 radiographs) at three sites.

Conclusion: The overlap of the oblique line over the image of the alveolar crests in the mandibular molar region was observed in a significant portion of the total sample.
\end{abstract}

Key words: Crestal bone; alveolar process; mandible

\section{Resumo}

Objetivo: Identificar e quantificar a frequência da projeção da linha oblíqua sobre as cristas alveolares dos molares inferiores em radiografias periapicais.

Metodologia: Foram selecionadas 500 radiografias periapicais da região de molares inferiores e avaliada a presença ou a ausência da linha oblíqua. Quando presente, foi analisada a interferência desta estrutura sobre a imagem das cristas alveolares dos molares inferiores. Os dados obtidos, considerando a frequência da sobreposição da linha oblíqua sobre as cristas alveolares dos molares inferiores foram expressos em percentagens.

Resultados: Nas 500 radiografias periapicais avaliadas, a linha oblíqua foi observada em 363 radiografias $(72,6 \%)$. Nestas, em $308(84,8 \%)$, houve sobreposição da linha oblíqua sobre as cristas alveolares. Entretanto, em 55 radiografias $(15,1 \%)$ não foi encontrada interferência. Nas radiografias em que houve a sobreposição da linha oblíqua sobre as cristas alveolares (308), a incidência de sobreposição em apenas um local foi de 64,6\% (199 radiografias); em dois locais foi de 33,4\% (103 radiografias) e em três locais foi de 1,9\% (6 radiografias).

Conclusão: A sobreposição da linha oblíqua sobre a imagem das cristas alveolares na região de molares inferiores representou uma fração significativa do total da amostra.

Palavras-chave: Crista alveolar; processo alveolar; mandíbula

\author{
Ruchielli Loureiro Borghetti a \\ Vanessa Paim Nora a \\ Luis César da Costa Filho a \\ Aline Rose Cantarelli Morosolli a \\ Maria Ivete Bolzan Rockenbach a
}

a Dental School, Pontifical Catholic University of Rio Grande do Sul, Porto Alegre, RS, Brazil

Correspondence:

Maria lvete Bolzan Rockenbach

Pontifical Catholic University of Rio Grande do Sul Av. Ipiranga, 6681 - Prédio 6 - Partenon Porto Alegre, RS - Brazil 90619-900

E-mail:ivete.rockenbach@pucrs.br

Received: April 28, 2010

Accepted: August 23, 2010

Conflict of Interest Statement: The authors state that there are no financial and personal conflicts of interest that could have inappropriately influenced their work.

Copyright: (c) 2010 Borghetti et al.; licensee EDIPUCRS. This is an Open Access article distributed under the terms of the Creative Commons AttributionNoncommercial-No Derivative Works 3.0 Unported License. 


\section{Introduction}

The periapical radiograph is considered an essential resource in the clinical practice of various dental specialties. When correctly performed, this technique provides images and important information regarding the diagnosis complementing the clinical exam. Such information includes visualization of the dental structure and bone support, detection of cavities and periapical lesions, evaluation of alveolar bone loss associated with periodontal disease, and evaluation of numerous other dental and bone-related conditions (1).

The visualization of some areas of the mandible during radiographic analysis is not always possible due to anatomical variations, which generate difficulties for image interpretation. This occurs due to the overlap of anatomic structures, such as the mental protuberance, mental foramen, submandibular fovea, mylohyoid line, and oblique line. Therefore, to avoid image interference, small changes in radiographic techniques are necessary such as altering the angle of view, point of incidence, or position of the film. Such modifications can enable a more precise radiographic analysis of the region (2-4).

Regarding the variability of the anatomic structures, it is known that these vary in shape, size, and position in different individuals, as well as within the same individual bilaterally (the left side vs. the right side). In addition, some structures do not appear at all in some radiographs (5).

The mandible is divided into two sections: the body and the ramus. The mandibular body includes the lower teeth with their respective alveolar processes. There are also anatomical landmarks of great relevance for the study of dentoalveolar anatomy, such as the mental eminence, lingual foramen, geniohyoid processes, mental foramen, part of mandibular canals (which is split into the incisive canals starting at the mental foramen), oblique lines, mylohyoid line, submandibular foveas and retromolar spaces. In the mandibular ramus, each side includes the head and neck of the mandible, mandibular notch, mandibular foramen, mandibular canal, lingual, and antilingula (6-8).

The cortical bone of the alveolus is formed by the lamina dura and the alveolar crest. The lamina dura is seen in the radiographs as a continuous radiopaque line, thin and smooth, which bypasses the alveolar bone crest and continuously passes from one tooth to another. Therefore, these radiographic elements become essential to the early diagnosis of periodontal disease. The radiographic image of the alveolar crest presents morphologic variations according to the convexity of the adjacent teeth, the distance between them, the degree of tooth eruption, slope, and height of the dentinoenamel junction. The alveolar process corresponds to the compact bone layer that covers the dental alveolus, enclosing the root (lamina dura) and limiting the interdental crest (alveolar crest) (5).

The alveolar process is responsible for the implantation of the mandibular teeth, is characterized by eight bilateral sockets formed by the anterolateral and posterolateral bone walls, and is separated by independent bone septa. The alveoli of the molar teeth are divided by the interradicular and interalveolar septa that reach the level of the alveolar surface (upper margin of mandibular body). The alveolar socket is formed by four walls: the buccal and the lingual surfaces as a continuum, and the mesial and distal surfaces which separate the alveoli (interalveolar septa) and are thus shorter, extending towards the buccal and lingual surfaces (9).

In the posterior region of the mandible the attachment of the alveolus to the bone becomes evident by the presence of an elevation known as oblique line. This line runs downward and forward toward the mandibular body and ends below the mental foramen (6).

The oblique line is considered a reinforcement and dissipation line of the mandible efforts. It is continuous with the anterior border of the ramus, reaching the distal side of the first molar, and serves as the attachment for some facial muscles $(5,9)$. Radiographically, the oblique line is seen as a highly radiopaque line found in the area of the mandibular molars traversing the last two molars at the level of the middle third of the root $(5,7)$. However, it is sometimes projected at the cervical third and can even overlap the alveolar crests, complicating the interpretation of periodontal disease (5).

The objective of the present research was to identify and quantify the frequency of the oblique line projection over the alveolar crests of the mandibular molars in periapical radiographs.

\section{Methods}

This study analyzed 500 periapical radiographs of the left and right sides of the mandibular molar region. These radiographs were from the archives of the Radiology Department of the Dental School of Pontifical Catholic University of Rio Grande do Sul. The sample was selected by a professor from this department, and the following criteria for quality control were considered: mean contrast and density, minimum distortion, vertical angle according to the Cieszynski rule, centric horizontal angle, safety margin of $3 \mathrm{~mm}$, and the free edge of the film parallel to the occlusal plane of the teeth.

All of the unidentified radiographs were placed in plastic assemblies to be analyzed on the same viewer with the aid of a 3x magnifying glass. Two calibrated observers examined each radiograph. Initially, the simple presence or absence of an oblique line was assessed. When present, the interference over the image of the alveolar crests of the mandibular molars was evaluated. The overlap of that structure was verified in the following regions: mesial to the first molar, between the first and second molars, between the second and third molars, and distal to the third molar. The data obtained regarding the frequency of the oblique line overlaps on the alveolar crests were expressed in percentages and organized into graphs and tables. 


\section{Results}

The obtained results showed that the oblique line was detected in 363 radiographs, representing $72.6 \%$ of the total sample of those 500 periapical radiographs selected from both sides of the mandibular molar regions (Fig. 1).

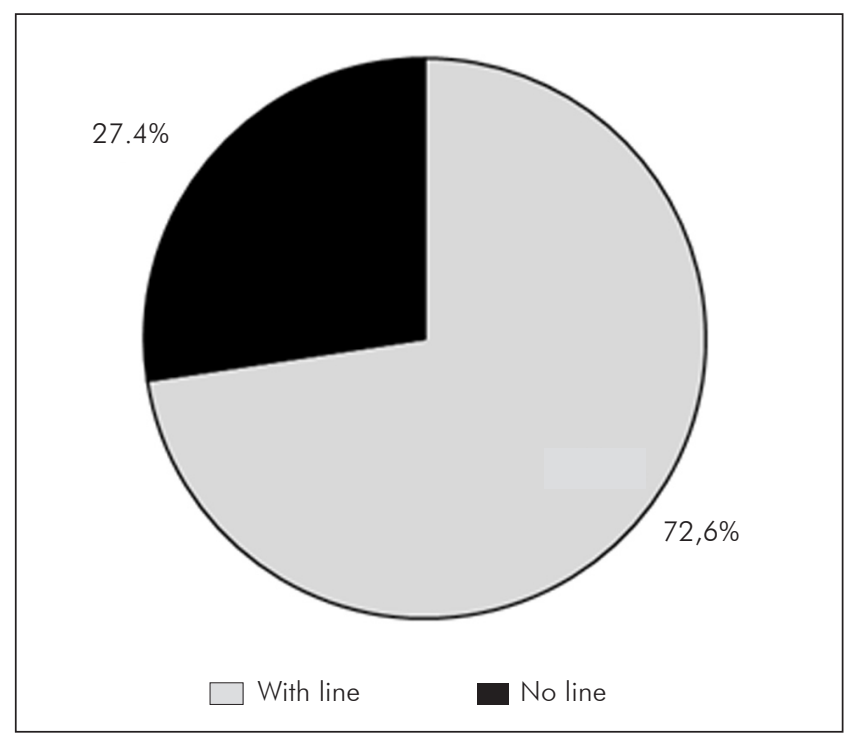

Fig. 1. Incidence of the oblique line in the periapical radiographs of the mandibular molar region.

Among the radiographs showing an oblique line (363), $308(84.8 \%)$ showed an overlap with the mandibular molar region. However, in 55 radiographs (15.1\%), the interference of the oblique line over the alveolar crests was not observed (Fig. 2).

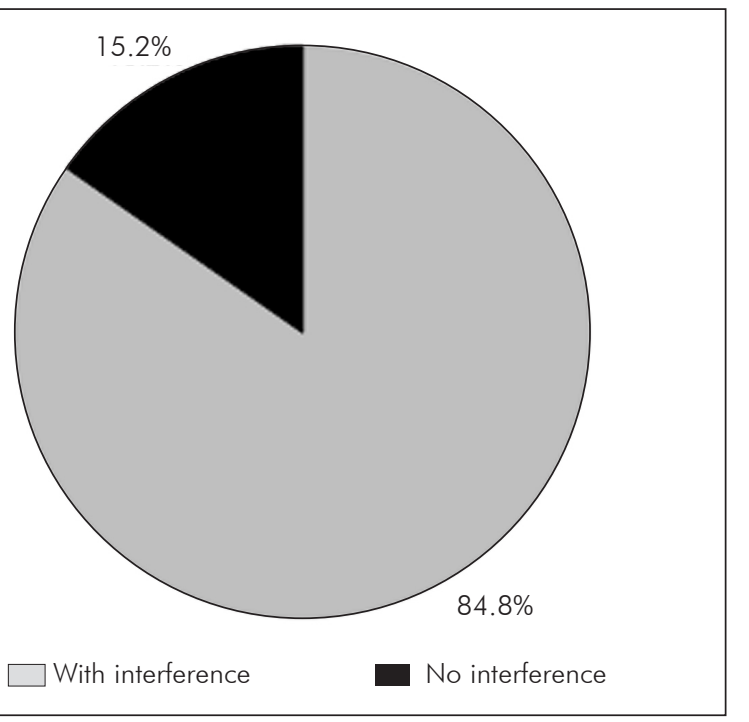

Fig. 2. Incidence of the interference of the oblique line over the alveolar crests in the mandibular molar region.
Among the radiographs that showed an overlap of the oblique line over the alveolar crests (308), the number of interferences was also analyzed, especially with regard to the anatomic site where the overlap occurred (one, two, or three sites). The incidence of the overlap was $64.6 \%$ (199 radiographs) in one site, $33.4 \%$ (103 radiographs) in two sites, and $1.9 \%$ (6 radiographs) in three sites (Fig. 3).

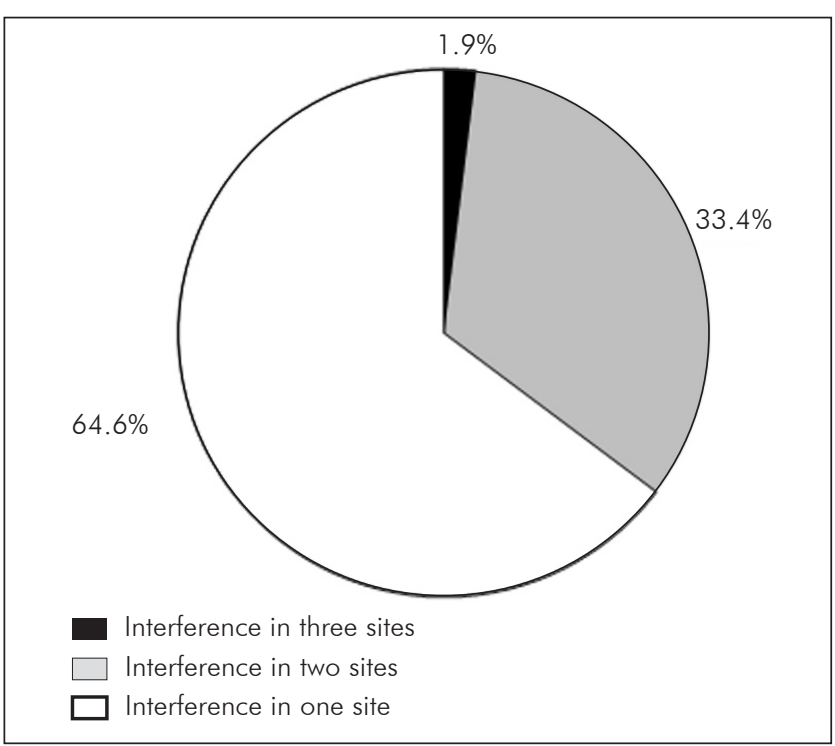

Fig. 3. The frequency of the oblique line in relation to the sites of interferences.

Considering the whole sample, the interference in one site was $39.8 \%$; in two sites, $20.6 \%$; and in three sites, $1.2 \%$ (Table 1).

Table 1. Incidence of the interference of the oblique line in relation to the total sample $(\mathrm{N}=500)$.

\begin{tabular}{lcccc}
\hline \multicolumn{1}{c}{ Type } & $\mathrm{N}$ & $\%$ & $\mathrm{Cl} 95 \%$ - SUP & $\mathrm{Cl95 \% -INF}$ \\
\hline $\begin{array}{l}\text { Interference } \\
\text { in 3 sites }\end{array}$ & 6 & 1.20 & 5.65 & 0.14 \\
$\begin{array}{l}\text { Interference } \\
\text { in 2 sites }\end{array}$ & 103 & 20.60 & 28.95 & 14.1 \\
$\begin{array}{l}\text { Interference } \\
\text { in 1 site }\end{array}$ & 199 & $39 ; 80$ & 48.96 & 31.27 \\
$\begin{array}{l}\text { No Interference } \\
\text { No line }\end{array}$ & 55 & 11.00 & 18.16 & 6.33 \\
\hline
\end{tabular}

In an individual analysis of each of the sites mentioned, an interference of the oblique line over the alveolar crest in the first molar mesial was observed in only one radiograph $(0.2 \%)$. The same interference was observed between the first and second molars in 18 radiographs (4.3\%). There was also interference between the second and the third molars in 222 radiographs (52.5\%). And there was interference in 182 radiographs $(43.0 \%)$ in the third molar distal. A total of 423 interferences in 308 radiographs were observed (Table 2). 
Table 2. Distribution of the sites of the interference $(N=423)$.

\begin{tabular}{lcccc}
\hline \multicolumn{1}{c}{ Sites } & $\mathrm{N}$ & $\%$ & $\mathrm{Cl} 95 \%-$ SUP & Cl95\% - INF \\
\hline M1 Molar & 1 & 0.24 & 3.71 & 0.006 \\
1-2 Molars & 18 & 4.26 & 9.43 & 1.74 \\
2-3 Molars & 222 & 52.48 & 60.89 & 43.94 \\
D3 Molar & 182 & 43.03 & 51.63 & 34.81 \\
\hline
\end{tabular}

\section{Discussion}

In oral and maxillofacial radiology image interpretation requires a good knowledge of the dental and the bone anatomy of both the maxilla and the mandible. Therefore it is important to distinguish between the features of normal anatomic structures and their variations to identify possible alterations (10). The periapical radiograph is undoubtedly the most commonly utilized imaging resource in dental practice due to its low cost, relatively simple equipment, easy acquisition, and straightforward interpretation of images (11). The disadvantage of this technique is the twodimensionality of the image, which does not permit in-depth visualization, i.e., in the buccal-lingual direction (12). A welldone radiographic projection in periapical impact assessment makes it possible to evaluate the position of the marginal alveolar bone as well as the bone destruction patterns of periodontal disease. This has been analyzed and demonstrated in many studies spanning many decades (13-15). The limitations of the periapical radiographs for the detection of bone defects have been frequently observed. These radiographs are hampered by the overlap of the roots and other anatomic structures associated with the reproduction of the radiographic image (12). Ramadan and Mitchel (14) have reported that vertical defects in the vestibular and lingual surfaces of the alveolar crest were only evident when there was a depth of at least $3 \mathrm{~mm}$. Defects ranging in depth from 1 to $2 \mathrm{~mm}$ were not visible in the radiographs. In a study by Rees et al. (15), regarding the radiographic image, two of the unidentified craters were approximately $1 \mathrm{~mm}$ in depth, whereas a third one located on the distal of the third mandibular molar was masked by the external oblique line of the mandible. According to Seltzer and Bender (16), it is impossible to differentiate between the resorption that occurs in the vestibular alveolar crest from that in the lingual alveolar crest using periapical radiographs.

According to Freitas et al. (7) the oblique line corresponds to the continuation of the anterior border of the mandibular ramus, which is located in the external surface of the mandibular body. This line is radiographically seen as a highly radiopaque stripe that is projected transversely in the mandibular body at the level of the middle third of the roots of the mandibular molars $(5,7)$.

According to Figún and Garino (9) this anatomical structure is considered a clear reinforcement line at the level of the alveoli of the mandibular molars, especially of the third molars, and it is presented with considerable development. However, the oblique line is often projected at the cervical thirds of the alveoli, overlapping with alveolar crests, which can hamper the interpretation of periodontal diseases (5). The results obtained in the present research confirm this finding showing a high percentage $(84.8 \%)$ of overlap of the oblique line over the alveolar crests in the mandibular molar region (Fig. 4A).

Some studies suggest alternatives to differentiate the image of the oblique line from the image of the alveolar crests in the mandibular molar region. A study by Ruffato et al. (2) suggests a variation in the vertical angles (15 positive degrees) in the inferior plane as a way to avoid the overlap of the mylohyoid line over the apices of the mandibular molars, especially of the first and second molars (Fig. 4B). This method of varying the periapical technique could also be applied to the mandibular molar region during the detailed evaluation of the alveolar crests.

The periapical radiograph is commonly used in dental practice (11), although sophisticated imaging resources used to complement the diagnosis of oral alterations, such as digital radiographs and cone-beam computed tomography, are now available. The latter, as a maxillofacial modality, has the advantage of achieving high-resolution threedimensional images. This is performed with low exposures to radiation, which is also important for the diagnosis of lesions in the oral cavity (17).
A

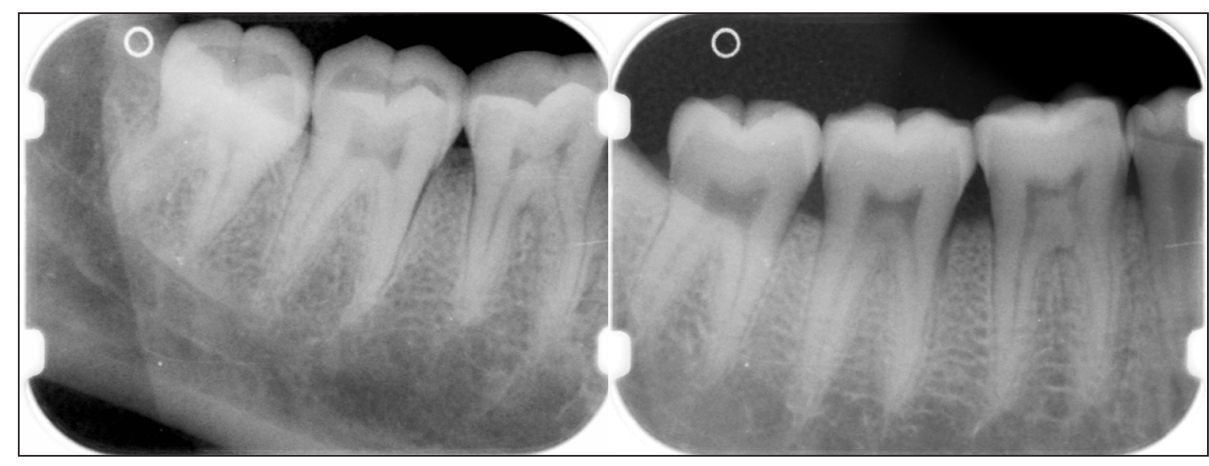

Fig. 4. (A) Periapical radiograph of the mandibular molar region showing the overlap of the oblique line over the image of the alveolar crests. (B) Periapical radiograph of the same mandibular molar region with the vertical angle variation (15 positive degrees). 
Thus it is relevant to suggest that the use of the vertical angle variation is an important resource for periapical radiographs which enables a more detailed analysis of the alveolar crest of the mandibular molar region. In addition, this change in the technique reduces the possible interference or overlap of the oblique line over anatomic structures. This is extremely important in the evaluation and in the treatment plan in patients with periodontal disease.

It is important to emphasize that periapical radiographs represent bidimensional images of three-dimensional anatomic structures. These radiographs need to be correctly performed and processed according to proper techniques. This is especially important in order to avoid inaccurate radiographic interpretations, misguided diagnoses, and consequently, compromised patient treatment.

\section{Conclusions}

Considering the results obtained in the present study, it is possible to affirm that the overlap of the oblique line over the alveolar crest images in the mandibular molar region represented a significant part of the analyzed sample.

\section{References}

1. White SC, Pharoah MJ. The evolution and application of the dental maxillofacial imaging modalities. Dent Clin N Am 2008;52: 689-705

2. Ruffato RJ, Selistre RCC, Rockenbach MI, Costa NP. Projeção da linha miloioidea na região de periápice de molares inferiores em radiografias periapicais. Rev Odonto Cienc 2002;17:405-8.

3. Kruter MC, Veeck EB, Costa NP, Rockenbach MI. Projeção da eminência mental na região de incisivos inferiores em radiografias periapicais. Rev Odonto Cienc 2003; 18:350-3.

4. Haesbaert BM, Oliveira PB, Rockenbach MI, Costa NP. Projeção da protuberância mental na região de canino inferior em radiografias periapicais. Rev Odonto Cienc 2004; 19:122-5.

5. Álvares LC, Tavano O. Curso de Radiologia em Odontologia. 4.ed. São Paulo: Santos, 1998. 248p.

6. Berkovitz BKB, Holland GR, Moxham BJ. Anatomia, embiologia e histologia bucal. 3. ed.Porto Alegre: Artmed, 2004. 378p

7. Freitas A, Salles AA, Freitas $C$, Sampaio GR. Anatomia radiográfica dentomaxilomandibular. In: Freitas A, Rosa JE, Souza IF. Radiologia Odontológica. 6.ed. São Paulo: Artes Médicas. 2004.833p.

8. Faig-Leite H, Kohatsu LI, Morosolli ARC, Moraes LC, Balducci I. Estudo radiográfico da localização da anti-língula em mandíbulas secas e sua relação com o forame da mandíbula. Cienc Odontol Bras $2004 ; 7: 74-8$
9. Figún ME, Garino RR. Anatomia odontológica - Funcional e aplicada. Porto Alegre: Artmed, 2003. 532p.

10. Antoniazzi MCC, Carvalho PL, Kpoide CH. Importância do conhecimento da anatomia radiográfica para a interpretação de patologias ósseas. RGO 2008;5:195-9.

11. Gröndahl H-G, Huumonen S. Radiographic manifestations of periapical inflammatory lesions. How new radiological techniques may improve endodontic diagnosis and treatment planning. Endodontic Topics 2004;8:55-67.

12. Estrela C. Ciências Endodônticas. São Paulo: Artes Médicas, 2004, $101 \mathrm{p}$.

13. Patur B. Roentgenographic evaluation of alveolar bone changes in periodontal disease. Dent Clin North Am 1960;2:47-54.

14. Ramadan ABG, Mitchell DF. A roentgenographic study of experimental bone destruction. Oral Surg 1962;15:934-43.

15. Rees TD, Biggs NL, Collings CK. Radiographic interpretation of periodontal osseous lesions. Oral Surg 1971;32:141-53.

16. Seltzer S, Bender JB. Roentgenographic and direct observation of experimental lesions in bone. II. J Am Dent Assoc 1961;62:152-60.

17. Terakado M, Hashimoto K, Arai Y, Honda M, Sekiwa T, Sato H. Diagnostic imaging with newly developed ortho cubic super high resolution computed tomography (ortho- CT). Oral Surg Oral Med Oral Pathol 2000;89:509-17. 